\title{
Keterampilan Mengajar Mahasiswa Calon Guru Biologi: Analisis Berbasis Gender
}

\section{Linda Tri Antika*, Moch. Haikal}

Pendidikan Biologi, Universitas Islam Madura, JL. Pondok Peantren Miftahul Ulum Bettet, Pamekasan (69317), JA-TIM, Indonesia

"Korespondensi penulis: lindatriantika@gmail.com

\begin{tabular}{|c|c|}
\hline Informasi artikel & ABSTRAK \\
\hline Riwayat artikel: & \multirow{5}{*}{$\begin{array}{l}\text { Keterampilan mengajar (teaching skills) adalah salah satu keterampilan } \\
\text { yang memberikan kontribusi besar bagi calon guru dalam rangka menjadi } \\
\text { guru profesional. Keterampilan ini memungkinkan bagi calon guru turut } \\
\text { andil dalam mencapai tujuan pendidikan nasional. Penelitian ini bertujuan } \\
\text { untuk mengetahui signifikansi perbedaan teaching skills mahasiswa calon } \\
\text { guru biologi laki-laki dan perempuan di era revolusi industri 4.0. Subyek } \\
\text { penelitian ini adalah mahasiswa Pendidikan Biologi semester } 4 \text { Tahun } \\
\text { Akademik 20I8/20I9. Penelitian ini merupakan penelitian kuantitatif } \\
\text { yang menggunakan analisis uji T untuk mengetahui signifikansi perbedaan } \\
\text { teaching skills pada mahasiswa laki-laki dan perempuan. Data teaching } \\
\text { skills didapatkan dari skor pada lembar asesmen teaching skills. Lembar } \\
\text { asesmen teaching skills yang digunakan memiliki empat aspek penilaian, } \\
\text { yaitu: I) membuka pelajaran; } 2 \text { ) melaksanakan kegiatan inti pembelajaran; } \\
\text { 3) menutup pembelajaran; dan 4) faktor penunjang. Masing-masing aspek } \\
\text { penilaian tersebut memiliki indikator dan deskriptor. Hasil penelitian } \\
\text { mengungkap bahwa tidak ada perbedaan signifikan teaching skills pada } \\
\text { mahasiswa calon guru biologi laki-laki dan perempuan. }\end{array}$} \\
\hline Diterima $\quad 04$ November 2019 & \\
\hline I5 Novembe & \\
\hline Dipublikasi 29 November 2019 & \\
\hline $\begin{array}{l}\text { Kata kunci: } \\
\text { Keterampilan mengajar, calon } \\
\text { guru biologi, gender. }\end{array}$ & \\
\hline
\end{tabular}

\section{ABSTRACT}

\section{Keywords:}

Learning outcomes, crosinterest, sparkol videoscribe, biology

\section{Teaching skills for prospective biology teachers: gender based analysis.} Teaching skill is one of the skills that make a major contribution to prospective teachers to become a professional teacher. These skills make it possible for teacher candidates to contribute in achieving national education goals. The objective of this study was to determine the significance of differences in teaching skills of prospective male and female biology teacher in industrial revolution 4.0 era. The subjects of this study were Biology Education students in $4^{\text {th }}$ semester of academic yeat 2018/2019. This research was a quantitative study using T-test analysis to determine the significance of differences in teaching skills of prospective male and female biology teacher. The teaching skills data were obtained from the scores on teaching skills assessment sheet. The teaching skills assessment sheet used has four aspects of assessment, namely: I) opening the lesson; 2) doing the core learning activities; 3) closing the lesson; and 4) supporting factors. Each aspect of the assessment has indicators and descriptors. The results showed that there were no significant differences in teaching skills of prospective male and female biology teacher.

(C) 2019 Antika \& Haikal This is an open access article under the CC-BY-SA license

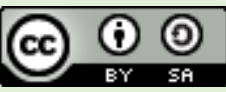

Sitasi: Antika, L.T., \& Haikal, L. (2019). Keterampilan mengajar mahasiswa calon guru biologi: Analisis berbasis gender. JPBIO (Jurnal Pendidikan Biologi), 4(2), IOI-I07. DOI: I0.31932/jpbio.v4i2.524 


\section{PENDAHULUAN}

Dewasa ini, bangsa Indonesia memiliki agenda besar, yaitu fokus dalam meningkatkan Sumber Daya Manusia (SDM) di berbagai bidang. Hal tersebut menjadi bahan pidato Presiden Republik Indonesia. Upaya peningkatan kualitas sumber daya manusia tersebut perlu dibarengi dengan pembekalan berbagai keterampilan dan ilmu pengetahuan. Pendidikan memiliki peran penting dalam mempersiapkan manusia-manusia unggul yang diharapkan dapat menata kehidupan bangsa Indonesia menjadi semakin maju. Memasuki era revolusi industri 4.0, masyarakat dituntut sadar bahwa pendidikan yang bermutu adalah syarat utama untuk mewujudkan kehidupan bangsa yang maju. Sementara itu, pendidikan yang bermutu sangat tergantung pada keberadaan guru yang bermutu pula, yaitu guru yang profesional.

Teaching skills (keterampilan mengajar) guru menjadi kunci keberhasilan suatu proses belajar mengajar.Teaching skills diartikan sebagai keterampilan teknik mengajar yang digunakan oleh guru dengan efektif untuk memberikan pembelajaran yang diinginkan terhadap peserta didik (Kumari \& Naik, 2016). Pembelajaran dapat dikatakan bermutu jika proses belajar mengajar berlangsung secara menarik dan menantang, sehingga peserta didik dapat belajar dan mendapatkan pengalaman sebanyak mungkin melalui proses belajar tersebut. Hal ini menjadi alasan mengapa teaching skills merupakan keterampilan utama yang harus dimiliki oleh seorang guru dan calon guru masa depan, baik laki-laki maupun perempuan.

Variabel strategi meliputi pengetahuan tentang pedagogik dan taktik yang guru gunakan untuk mengatasi berbagai situasi di dalam kelas (Jiang et al., 2016). Penelitian terdahulu memberikan gambaran adanya perbedaan guru laki-laki dan perempuan dalam hal kecerdasan emosi (Rachman \& Tjalla, 2008; Meshkat \& Nejati, 2017; Ajmal et al., 2017 ). Bahkan, perbedaan struktur otak dan perilaku belajar antara laki-laki dan perempuan dibahas dengan rinci (Amin, 2018). Guru laki-laki lebih banyak meluangkan waktu untuk kepentingan kegiatan sekolah dibandingkan guru perempuan yang memiliki banyak kepentingan di luar sekolah (Sukarti, 2013), sehingga dapat mempengaruhi kinerja dan pemberdayaan keterampilan yang dimiliki oleh guru tersebut, terutama pengelolaan pembelajaran. Selain itu, terkait dengan keterampilan berpikir kritis sebagai calon guru, perempuan memiliki keterampilan berpikir kritis yang lebih tinggi dibandingkan laki-laki (Cahyono, 2017).

Lebih lanjut, penelitian lain mengungkap hasil sebaliknya. Kajian hubungan tingkat keterampilan mengajar guru perempuan dengan hasil belajar peserta didik telah dilaporkan bahwa ada hubungan yang signifikan antara kedua variabel tersebut (Nurhikmah, 2018). Penelitian etos kerja guru laki-laki dan perempuan juga telah diteliti dengan laporan bahwa etos kerja guru laki-laki dan perempuan sama-sama berada pada kategori tinggi (Hafiz \& Jumriadi, 2018).

Penelitian terdahulu masih terbatas dalam mengungkap bagaimana teaching skills guru laki-laki dan perempuan, serta belum mengungkap teaching skills calon guru di Indonesia. Oleh karena itu, peneliti merasa perlu membahas teaching skills pada calon guru, dimana dalam penelitian ini adalah calon guru biologi. Empat aspek teaching skills pada penelitian ini yaitu: I) membuka pelajaran; 2) melaksanakan kegiatan inti pembelajaran; 3) menutup pembelajaran; dan 4) faktor penunjang. Masing-masing aspek penilaian tersebut memiliki indikator dan deskriptor. Penelitian ini berbasis gender, dimana penelitian ini akan membahas signifikansi perbedaan teaching skills pada calon guru biologi laki-laki dan perempuan.

\section{METODE PENELITIAN \\ Rancangan Penelitian}

Penelitian ini merupakan penelitian kuantitatif dengan rancangan penelitian quasi experiment, dimana analisis pada penelitian ini adalah analisis berbasis gender. Penelitian ini akan mengungkap signifikansi perbedaan teaching skills pada calon guru biologi laki-laki dan perempuan.

\section{Populasi dan Sampel Penelitian}

Populasi penelitian ini adalah mahasiswa pada Fakultas Keguruan dan Ilmu Pendidikan (FKIP) Universitas Islam Madura (UIM). Adapun sampel dalam penelitian ini adalah mahasiswa pendidikan biologi angkatan 2017 yang berjumlah 22 mahasiswa (I0 laki-laki dan 12 perempuan). Penentuan sampel pada penelitian ini dilakukan dengan teknik random sampling.

\section{Instrumen Penelitian}

Instrumen penelitian yang digunakan adalah lembar asesmen teaching skills. Lembar asesmen teaching skills yang digunakan memiliki empat aspek penilaian yaitu: (I) membuka pelajaran; (2) melaksanakan kegiatan inti pembelajaran; (3) menutup pembelajaran; dan (4) faktor penunjang. Masing-masing aspek penilaian tersebut 
memiliki indikator dan deskriptor tersendiri. Instrumen ini telah diuji coba pada tiga angkatan mahasiswa Pendidikan Biologi Universitas Madura. Tabel I memaparkan aspek penilaian dan indikator teaching skills yang digunakan dalam penelitian.

Tabel I. Tabel aspek penilaian dan indikator teaching skills

\begin{tabular}{|c|c|c|}
\hline No & Aspek Penilaian & Indikator \\
\hline \multirow[t]{2}{*}{ I } & \multirow{2}{*}{ Membuka pembelajaran } & - Motivasi \\
\hline & & - Apersepsi \\
\hline \multirow[t]{4}{*}{2} & \multirow{4}{*}{$\begin{array}{l}\text { Melaksanakan kegiatan } \\
\text { inti pembelajaran }\end{array}$} & - Penggunaan metode pembelajaran \\
\hline & & - Ketepatan materi/ konsep \\
\hline & & - Penguasaan kompetensi melaksanakan pembelajaran \\
\hline & & - Penggunaan media pembelajaran \\
\hline 3 & Menutup pembelajaran & - Refleksi dan penilaian \\
\hline 4 & Faktor penunjang & - Penggunaan bahasa, pengaturan waktu, percaya diri, dan penampilan \\
\hline
\end{tabular}

Prosedur Penelitian

Penelitian ini dilakukan pada mahasiswa semester 4 angkatan 2017 dalam matakuliah Strategi Belajar Mengajar (SBM). Pada penelitian ini, mahasiswa melakukan modeling individu secara komprehensif, mulai dari membuka pelajaran hingga menutup pelajaran. Kegiatan modeling mahasiswa dinilai oleh dosen dan observer melalui lembar asesmen khusus teaching skills. Hasil asesmen tersebut kemudian direkap dan dianalisis menggunakan SPSS 22.0 for Windows.

\section{Teknik Analisis Data}

Analisis data dilakukan dengan bantuan program SPSS 22.0 for Windows. Sebelum dilakukan uji hipotesis penelitian, terlebih dahulu akan dilakukan uji normalitas dan homogenitas data. Hipotesis penelitian yang diajukan akan diuji dengan Independent Sample T-test dengan taraf signifikansi 0,05 $(\mathrm{P}<0,05)$ menggunakan data teaching skills mahasiswa calon guru biologi. Berdasarkan hasil analisis akan diketahui apakah ada perbedaan teaching skills pada mahasiswa calon guru laki-laki dan perempuan.

\section{HASIL PENELITIAN}

\section{Deskripsi Data Hasil Penelitian}

Data penelitian diperoleh dari mahasiswa Pendidikan Biologi yang berjumlah 22 mahasiswa. Data yang telah diperoleh pada penelitian ini meliputi data teaching skills mahasiswa calon guru biologi yang digunakan untuk mengetahui teaching skills mahasiswa melalui analisis uji $\mathrm{T}$ dalam rangka mengetahui apakah ada perbedaan teaching skills mahasiswa calon guru laki-laki dan perempuan. Data skor dan rata-rata teaching skills mahasiswa dapat dilihat pada Tabel 2.

Tabel 2. Skor dan rata-rata teaching skills

\begin{tabular}{|c|c|c|c|c|c|}
\hline No & Mahasiswa Calon Guru & Teaching Skills & No & Mahasiswa Calon Guru & Teaching Skills \\
\hline 1 & Ach. Fahrurrozy & 80,3 & 13 & Moh. Husyin Abdullah & 81,8 \\
\hline 2 & Annis Watun & 81,9 & 14 & Moh. Wawan Efendi & 85,5 \\
\hline 3 & Atikul Mukarromah & 80,5 & 15 & Muhammad Nur Hidayat & 85,0 \\
\hline 4 & Badriyatul Khoiriyah & 87,5 & 16 & Munirah & 88,8 \\
\hline 5 & Baidawi & 87,3 & 17 & Mutiatul Jannah & 88,8 \\
\hline 6 & Ema Sari & 78,5 & 18 & Rifqi Ansyari & 83,8 \\
\hline 7 & Fitriyatun Nisak & 82,0 & 19 & Sholehuddin & 84,3 \\
\hline 8 & Halimah & 79,3 & 20 & Sitti Hamsiyatul Jannah & 88,3 \\
\hline 9 & Irfan Efendi & 85,3 & 21 & Susi Nurfitriyah & 80,3 \\
\hline 10 & Izzetun Namiroh & 84,4 & 22 & Syamsudin & 76,5 \\
\hline 11 & Luluk Ilmanun & 79,3 & \multirow{2}{*}{\multicolumn{2}{|c|}{ Rata-Rata }} & 83,53 \\
\hline 12 & Moh. Arif & 88,3 & & & \\
\hline
\end{tabular}


Tabel 2 menunjukkan bahwa rata-rata teaching skills mahasiswa adalah 83,53 yang dapat dikategorikan tinggi. Adapun perbedaan rata-rata teaching skills calon guru biologi laki-laki dan perempuan dapat dilihat pada Tabel 3 dan Tabel 4.

Tabel 3. Skor dan rata-rata teaching skills pada calon guru laki-laki

\begin{tabular}{clc}
\hline No. & Mahasiswa Calon Guru & Teaching Skills \\
\hline I & Ach. Fahrurrozy & 80,3 \\
\hline 2 & Baidawi & 87,3 \\
\hline 3 & Irfan Efendi & 85,3 \\
\hline 4 & Moh. Arif & 88,3 \\
\hline 5 & Moh. Husyin Abdullah & 81,8 \\
\hline 6 & Moh. Wawan Efendi & 85,5 \\
\hline 7 & Muhammad Nur Hidayat & 85,0 \\
\hline 8 & Rifqi Ansyari & 83,8 \\
\hline 9 & Sholehuddin & 84,3 \\
\hline I0 & Syamsudin & 76,5 \\
\hline \multicolumn{2}{c}{ Rata-rata } \\
\hline
\end{tabular}

Tabel 4. Skor dan rata-rata teaching skills pada calon guru perempuan

\begin{tabular}{clc}
\hline No. & \multicolumn{1}{c}{ Mahasiswa Calon Guru } & Teaching Skills \\
\hline I & Annis Watun & $8 \mathrm{I}, 9$ \\
\hline $\mathbf{2}$ & Atikul Mukarromah & 80,5 \\
\hline $\mathbf{3}$ & Badriyatul Khoiriyah & 87,5 \\
\hline $\mathbf{4}$ & Erna Sari & 78,5 \\
\hline $\mathbf{5}$ & Fitriyatun Nisak & 82,0 \\
\hline $\mathbf{6}$ & Halimah & 79,3 \\
\hline $\mathbf{7}$ & Izzetun Namiroh & 84,4 \\
\hline $\mathbf{8}$ & Luluk Ilmanun & 79,3 \\
\hline $\mathbf{9}$ & Munirah & 88,8 \\
\hline I0 & Mutiatul Jannah & 88,8 \\
\hline II & Sitti Hamsiyatul Jannah & 88,3 \\
\hline I2 & Susi Nurfitriyah & 80,3 \\
\hline \multicolumn{2}{c}{ Rata-rata } \\
\hline
\end{tabular}

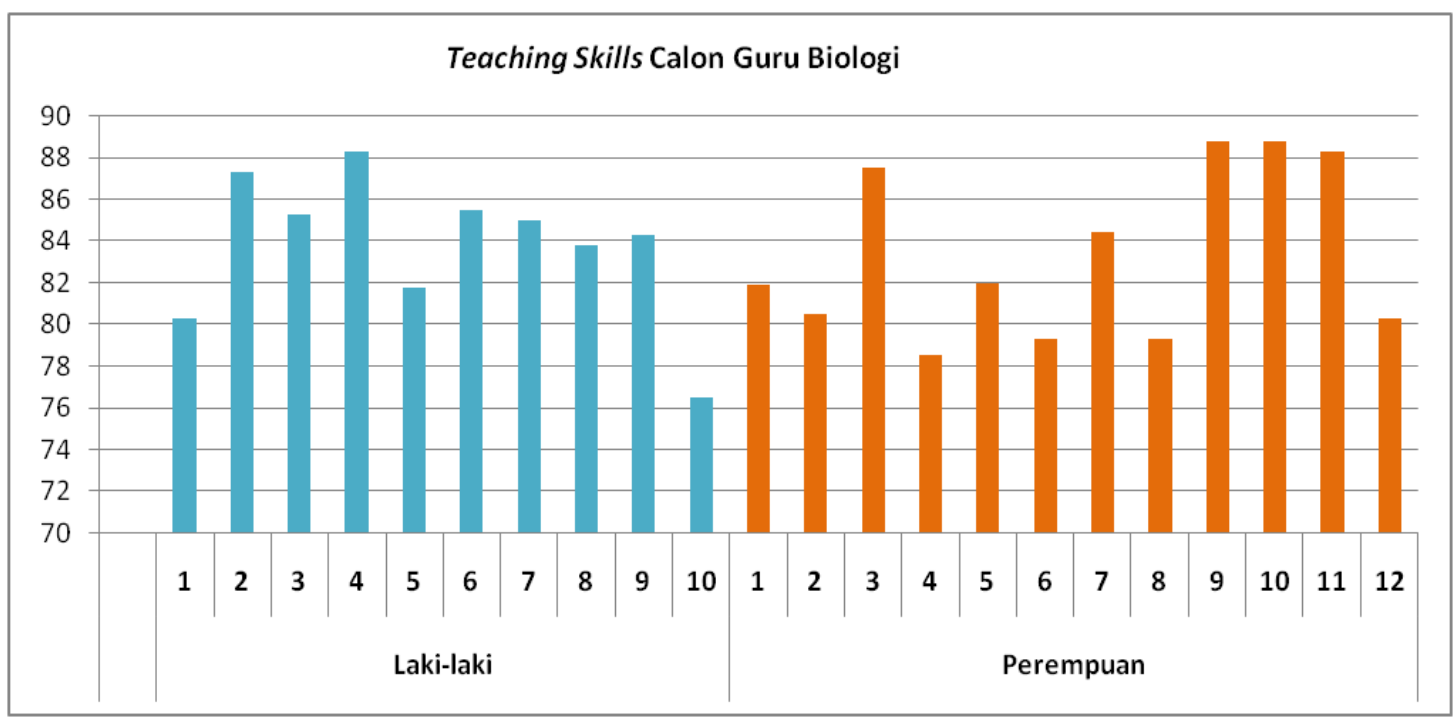

Gambar I. Profil skor teaching skills calon guru biologi laki-laki dan perempuan 
Tabel 3 menunjukkan bahwa rata-rata teaching skills calon guru biologi laki-laki sebesar 83,8I, sedangkan Tabel 4 menunjukkan bahwa rata-rata teaching skills calon guru biologi perempuan adalah 83,3. Angka tersebut menunjukkan bahwa rata-rata calon guru laki-laki dan perempuan memiliki selisih yang tidak besar, yakni 0,5I. Profil skor teaching skills calon guru biologi laki-laki dan perempuan dapat dilihat pada Gambar I.

\section{Hasil Uji Hipotesis}

Hasil analisis uji Tdilakukan untuk mengetahui apakah adaperbedaan teaching skills mahasiswa calon guru biologi laki-laki dan perempuan. Hasil uji T dapat dilihat pada Tabel 5.

Tabel 5. Hasil uji hipotesis dengan $t$-test

\begin{tabular}{|c|c|c|c|c|c|c|c|c|c|c|}
\hline & & $\begin{array}{c}\text { Levc } \\
\text { Test } \\
\text { Equal } \\
\text { Vari }\end{array}$ & $\begin{array}{l}\text { ne's } \\
\text { for } \\
\text { ity of } \\
\text { nces }\end{array}$ & & & & st for Equali & of Means & & \\
\hline \multirow{4}{*}{$\begin{array}{l}\text { Teaching } \\
\text { Skills }\end{array}$} & & \multirow[t]{2}{*}{$\mathrm{F}$} & \multirow[t]{2}{*}{ Sig. } & \multirow[t]{2}{*}{$\mathrm{t}$} & \multirow[t]{2}{*}{$\mathrm{df}$} & \multirow{2}{*}{$\begin{array}{l}\text { Sig. } \\
(2- \\
\text { tailed })\end{array}$} & \multirow[t]{2}{*}{$\begin{array}{c}\text { Mean } \\
\text { Difference }\end{array}$} & \multirow[t]{2}{*}{$\begin{array}{l}\text { Std. Error } \\
\text { Difference }\end{array}$} & \multicolumn{2}{|c|}{$\begin{array}{l}\text { 95\% Confidence } \\
\text { Interval of the } \\
\text { Difference }\end{array}$} \\
\hline & & & & & & & & & Lower & Upper \\
\hline & $\begin{array}{l}\text { Equal } \\
\text { variances } \\
\text { assumed }\end{array}$ & 1.470 & .240 & .313 & 20 & .757 & .5100 & 1.6269 & - & 3.9037 \\
\hline & $\begin{array}{l}\text { Equal } \\
\text { variances } \\
\text { not } \\
\text { assumed }\end{array}$ & & & .318 & 19.967 & .754 & .5100 & 1.6039 & $\begin{array}{r}- \\
2.8360\end{array}$ & 3.8560 \\
\hline
\end{tabular}

Berdasarkan Tabel 5 dapat dilihat bahwa nilai t lebih besar dari level of significant,yaitu 0,757 >0,05. Dengan demikian, ini mengindikasikan bahwa tidak ada perbedaan yang signifikan antara teaching skills calon guru biologi laki-laki dan perempuan

\section{PEMBAHASAN}

Hasil analisis data perbedaan teaching skills mahasiswa calon guru biologi berdasarkan gender menunjukkan bahwa tidak ada perbedaan yang signifikan teaching skills calon guru biologi laki-laki dan perempuan. Ini mengindikasikan bahwa baik mahasiwa calon guru biologi laki-laki maupun perempuan menghadapi permasalahan keterampilan mengajar yang tidak jauh berbeda. Penelitian ini sejalan dengan penelitian terdahulu, kaitannya dengan kemampuan dalam berpikir dalam menunjang teaching skills yang dimiliki calon guru laki-laki maupun perempuan. Gender, prestasi, dan status sosial ekonomi tidak mempengaruhi kemampuan berpikir peserta didik (Heong et al., 20II; Whitney et al., 2016). Penelitian lain juga melaporkan bahwa perbedaan jenis kelamin tidak menunjukkan perbedaan yang signifikan dalam hal kemampuan berpikir (Reese et al., 2009). Lebih lanjut, etos kerja guru laki-laki dan perempuan sama-sama berada pada kategori tinggi (Hafiz \& Jumriadi, 2018).

Selain kemampuan berpikir, kreativitas juga sangat mendukung teaching skills seorang calon guru dalam menciptakan pembelajaran yang bermakna dan menyenangkan bagi peserta didik. Penelitian terdahulu mengungkap bahwa kreativitas pada laki-laki dan perempuan adalah sama (Suprapto et al., 20I8; Abraham, 2016). Penelitian ini mengindikasikan bahwa calon guru laki-laki maupun perempuan memiliki potensi yang sama dalam mengupayakan pembelajaran yang kreatif dan menyenangkan. Kreativitas calon guru dalam penelitian ini tampak pada kreativitas dalam menyampaikan apersepsi, penggunaan metode pembelajaran, penyampaian materi atau konsep, serta penggunaan media pembelajaran.

Hasil penelitian ini tidak sejalan dengan temuan beberapa peneliti terkait dengan gender dan kemampuan yang terkait dengan teaching skills. Perempuan lebih unggul dalam kemampuan verbal (Sasser, 2010) dan kemampuan berpikir kritis (Fuad, 2017). Perempuan lebih baik dalam hal berbahasa (Sasser, 2010; Zaidi, 2010). Selain itu, dalam pembelajaran laki-laki cenderung kurang teliti jika dibandingkan dengan perempuan 
(Hindal et al., 2013). Hasil ini sebenarnya dapat terlihat pada hasil penelitian ini, yaitu pada nilai rerata teaching skills yang menunjukkan bahwa rerata teaching skills mahasiswa calon guru perempuan memiliki nilai yang lebih tinggi dibandingkan dengan rerata teaching skills mahasiswa calon guru laki-laki. Akan tetapi, selisih dari rerata teaching skills keduanya hanya 0,5I. Dengan kata lain, teaching skills mahasiswa calon guru biologi laki-laki dan perempuan tidak jauh berbeda.

Pembelajaran yang dilakukan dalam proses penelitian ini adalah pembelajaran yang memberdayakan keterampilan metakognitif, yang memungkinkan mahasiswa calon guru melakukan planning, monitoring, evaluating, dan revising. Kegiatan tersebut memberikan kesempatan yang sama bagi mahasiswa calon guru untuk melakukan perencanaan pembelajaran semaksimal mungkin, memonitor sendiri pembelajaran yang diciptakan, mengevaluasi, lalu kemudian melakukan evaluasi apabila terdapat hal yang perlu diperbaiki. Dengan kegiatan ini, mahasiswa calon guru dapat mengetahui kekurangan dan kelebihan dalam mengajar, sehingga tahu tindakan apa yang selanjutnya perlu dilakukan demi perbaikan pembelajaran. Eggen \& Kauchak (1996) dan Dewi et al., (2018) mengungkap bahwa dengan pembelajaran yang tepat dan kooperatif, maka setiap individu akan mendapatkan kesempatan sama untuk sukses, termasuk sukses menjadi calon guru yang professional. Dunbsky \& Metcal (2008) dan Bustami et al., (2018) menjelaskan bahwa aktivitas yang terlibat dalam belajar seperti penggunaan model pembelajaran yang tepat dapat meningkatkan kemampuan memecahkan masalah, kemampuan berpikir kritis dan membuat perkiraan kinerja yang merupakan keterampilan metakognitif.

\section{SIMPULAN}

Hasil penelitian ini dapat disimpulkan bahwa tidak ada perbedaan yang signifikan antara teaching skills calon guru laki-laki dan perempuan. Penelitian ini juga memberikan gambaran bahwa calon guru biologi laki-laki maupun perempuan memiliki potensi yang sama dalam memberdayakan teaching skills masing-masing. Penelitian ini memberikan dampak positif bagi perkembangan keterampilan mengajar mahasiswa calon guru biologi, sebab pembelajaran yang diterapkan dalam penelitian ini adalah pembelajaran yang memberdayakan keterampilan metakognitif, dimana mahasiswa calon guru dapat merencanakan, memonitor, mengevaluasi, dan merevisi sendiri perkembangan teaching skillsnya.

\section{UCAPAN TERIMAKASIH}

Ucapan terimakasih disampaikan pada Kemenristek Dikti yang telah mendanai penelitian ini melalui hibah Penelitian Dosen Pemula Tahun Anggaran 2019.

\section{REFERENSI}

Abraham, A. (2016). Gender and creativity: An overview of psychological and neuroscinetific literature. Brain Imaging and Behavior, IO(2), 609-6I8. DOI: I0.1007/sII682-0I5-94I0-8

Ajmal, S., Javed, S., \& Javed, H. (2017). Gender differences in emotional intelligence among medical students. International Journal of Business and Social Science, 8(3), 205-207. http://ijbssnet.com/journal/index/3740

Amin, M.S. (2018). Perbedaan struktur otak dan perilaku belajar antara pria dan wanita; Eksplanasi dalam sudut pandang neuro sains dan filsafat. Jurnal Filsafat Indonesia, I(I), 38-43. DOI: I0.23887/jfi.vIiI.I3973

Bustami, Y., Syafruddin, D., \& Afriani, R. (2018). The implementation of contextual learning to enhance biology students' critical thinking skills. Jurnal Pendidikan IPA Indonesia, 7(4), 45I-457. DOI: I0.I5294/jpii.v7i4.II72I

Cahyono, B. (2017). Analisis keterampilan berpikir kritis dalam memecahkan masalah ditinjau perbedaan gender. Jurnal Matematika dan Pendidikan Matematika, 8(I), 50-64. DOI: I0.26877/aks.v8iI.I5I0

Dewi, R., Ege B., \& Syafruddin, D. (2018). Pengaruh model pembelajaran kooperatif tipe cooperative, integrated, reading, and composition berbasis media peta konsep terhadap kemampuan berpikir kritis siswa pada materi sistem pencernaan manusia. JPBIO (Jurnal Pendidikan Biologi), 3(2), 3I-40. DOI: 10.31932/jpbio.v3i2.307

Dunbsky, J., \& Metcal, S.J. (2008). Metacognition. Thousand Oaks: C. A Sage.

Eggen, P.D., \& Kauchak, D.P. (1996). Strategies for teacher: teaching content and thinking skills. Boston: Allyn $\&$ Bacon.

Fuad, N.M., Zubaidah, S., Mahanal, S., \& Suarsini, E. (2017). Improving junior high schools' critical thinking skills based on test three different models of learning. International Journal of Instruction, IO(I), IOIII6. DOI: I0.12973/iji.2017.I0I7a 
Hafiz, H.A., \& Jumriadi, J. (2018). Hubungan pembinaan kemampuan mengajar guru dan etos kerja guru sekolah menengah pertama (SMP) negeri kabupaten Tabalong. Jurnal Tarbiyah: Jurnal Ilmiah Kependidikan, 7(2), I23-132. DOI: I0.18592/tarbiyah.v7i2.2246

Heong, Y.M., Othman, W.B., Yunos, J.B.M., Kiong, T.T., Hassan, R.B., \& Mohamad, M.M.B. (20II). The level of mazarno higher order thinking skills among technical education students. International Journal of Social Science and Humanitiy, I(2), I2I-I25. http://ijssh.org/papers/20-H009.pdf

Hindal, H., Reid, N., \& Whitehead, R. (2013). Gender and learner characteristics. European Journal of Educational Research, 2(2), 83-96. DOI: I0.12973/eu-jer.2.2.83

Jiang, Y., Ma, L., \& Gao, L. (2016). Assessing teachers' metacognition in teaching: the teacher metacognition inventory. Teaching and Teacher Education, 59, 403-4I3. DOI: I0.I0I6/j.tate.2016.07.014

Kumari, V., \& Naik, S.P. (2016). Effect of reflective teaching training and teaching aptitude on teaching skills among elementary teacher trainees. I-manager's Journal on Educational Psycology, 9(3), I I-23. DOI: I0.26634/jpsy.9.3.3769

Meshkat, M., \& Nejati, R. (2017). Does emotional intelligence depend on gender? a study on undergraduate english majors of three Iranian Universities. Journal Sage Open, 7(3), I-8. DOI: I0.II77/2I582440I7725796

Nurhikmah, N. (2018). Hubungan tingkat keterampilan mengajar guru perempuan pada bidang studi pendidikan agama islam terhadap hasil belajar peserta didik di smp muhammadiyah limbung kec. bajeng kab. Gowa. An-Nisa', II(I), 307-323. DOI : I0.30863/an.vI IiI.298

Rachman, M.P., \& Tjalla, A. (2008). Keterampilan pengelolaan kelas dilihat dari jenis kelamin dan kecerdasan emosi guru sekolah luar biasa. Jurnal Psikologi, 2(I), I-7. https://ejournal.gunadarma.ac.id/index.php/psiko/article/view/238

Reese, H.W., Lee, L., Cohen, S.H., \& Pucket, J.M. (2009). Effects of intellectual variables, age, and gender on divergent thinking in adulthood. International Journal of Behavioral Development, 25(6), 49I-500. DOI: I0.1080/0I650250042000483

Sasser, L. (2010). Brain differences between genders: Gender differences in learning. Genesis, 5, I-2.

Sukarti, S. (2013). Isu gender dan sertifikasi guru versus prestasi belajar siswa. Jurnal Pendidikan, I4(I), 38-43. http://ilp.ut.ac.id/JP/article/view/I64

Suprapto, S., Zubaidah, S., \& Corebima, A.D. (2018). Pengaruh gender terhadap keterampilan berpikir kreatif siswa pada pembelajaran biologi. Jurnal Pendidikan: Teori, Penelitian, dan Pengembangan, 3(3), 325329. DOI: $10.17977 /$ jptpp.v3i3.10642

Whitney, E.M., Aleksejuniene J., \& Walton, J.N. (2016). Critical thinking disposition and skills in dental students: development and relationship to academic outcomes. Journal of Dental Education, 80(8), 948958. http://www.jdentaled.org/content/80/8/948

Zaidi, Z.F. (2010). Gender differences in human brain: A review. The Open Anatomy Journal, 2010, 2, 37-55. DOI: $10.2174 / 1877609401002010037$ 